\title{
Strategi Komunikasi Pemasaran selama Masa Pandemi COVID-19 (Studi Kopi Uda di Alun-Alun Sungai Kapuas Kabupaten Sintang)
}

\author{
Aldona Nevi Caroline ${ }^{1}$, Farid Rusdi ${ }^{2 *}$ \\ ${ }^{1}$ Fakultas Ilmu Komunikasi Universitas Tarumanegara \\ Email: aldona.915170141@stu.untar.ac.id \\ ${ }^{2}$ Fakultas Ilmu Komunikasi Universitas Tarumanegara* \\ Email: farid@fikom.untar.ac.id
}

Masuk tanggal : 15-12-2021, revisi tanggal : 06-01-2022, diterima untuk diterbitkan tanggal : 16-01-2022

\begin{abstract}
The Corona Virus (COVID-19) has begun to spread to Indonesia since March 2020 and the increased case of COVID-19 proved to have quite a significant impact on the economy globally which may have affected stability in Indonesia. The people of Sintang District have also experienced economic problems due to the pandemic, one of which is Kopi Uda. Kopi Uda is a coffee shop located in Kapuas River Square which started its business in 2019 by selling various variants of drinks. However, when the beginning of this pandemic, the community reduced their activities outside the home and this resulted in the sale of Kopi Uda becoming uncertain and even experiencing a significant decline. This research was conducted to explain the marketing communication strategy carried out by Kopi Uda during the COVID19 pandemic. The approach used in this research is descriptive qualitative and type of case studies. The research subject in this thesis is Kopi Uda which is located at Kapuas River Square, Jalan Pembangunan, Tanjung Puri, Sintang Regency. While the object of research in this thesis is the marketing communication strategy carried out by Kopi Uda during the COVID-19 pandemic. Data were collected by interview, observation, documentation, and literature study. The conclusion of this study is that promotion, public relations, and direct marketing are the areas of activity most frequently used by Kopi Uda in marketing communications during the COVID-19 pandemic.
\end{abstract}

Keywords: communication strategy, COVID-19 pandemic, marketing

\begin{abstract}
Abstrak
Abstrak: Sejak Maret 2020 ketika Virus Corona (COVID-19) mulai merabah ke Indonesia dan berdampak bagi sektor ekonomi di Indonesia. Masalah perekonomian akibat pandemi juga dirasakan oleh masyarakat Kabupaten Sintang salah satunya Kopi Uda. Kopi Uda merupakan salah satu kedai kopi yang berada di Alun-Alun Sungai Kapuas yang memulai usahanya pada tahun 2019 dengan menjual berbagai varian minuman. Namun, ketika awal munculnya pandemi ini, masyarakat mengurangi aktivitas di luar rumah dan hal ini berakibat pada penjualan Kopi Uda menjadi tak tentu bahkan mengalami penurunan signifikan. Penelitian ini dilakukan untuk menjelaskan strategi komunikasi pemasaran yang dilakukan Kopi Uda selama masa pandemi COVID-19. Pendekatan yang digunakan dalam penelitian ini adalah kualitatif deskriptif dan jenis studi kasus. Subjek penelitian dalam skripsi ini adalah Kopi Uda yang beralamat di Alun-Alun Sungai Kapuas Jalan Pembangunan, Tanjung Puri, Kabupaten Sintang. Sedangkan objek penelitian dalam skripsi ini adalah strategi komunikasi pemasaran yang dilakukan Kopi Uda selama masa pandemi COVID-19. Data dikumpulkan dengan wawancara, observasi, dokumentasi, dan studi pustaka. Hasil penelitian menunjukkan bahwa promosi, hubungan masyarakat dan pemasaran langsung merupakan bidang aktivitas yang paling efektif bagi Kopi Uda dalam melakukan komunikasi pemasaran selama masa pandemi COVID-19.
\end{abstract}


Kata kunci: pandemi COVID-19, pemasaran, strategi komunikasi

\section{Pendahuluan}

Sejak Maret 2020 ketika Virus Corona (COVID-19) mulai merabah ke Indonesia, tidak sedikit sektor yang terdampak akibat pandemi ini, salah satunya adalah terhadap sektor ekonomi di Indonesia. Masalah perekonomian akibat pandemi juga dirasakan oleh masyarakat Kabupaten Sintang khususnya pedagang-pedagang makanan dan jajanan di sekitar alun-alun Sungai Kapuas, salah satunya Kopi Uda. Kopi Uda merupakan salah satu kedai kopi yang berada di Alun-Alun Sungai Kapuas yang memulai usahanya pada tahun 2019.

Selain kopi, Kopi Uda juga menyediakan berbagai varian minuman lainnya serta makanan. Namun, ketika awal munculnya pandemi ini, masyarakat mengurangi aktivitas di luar rumah dan hal ini berakibat pada penjualan Kopi Uda menjadi tak tentu bahkan mengalami penurunan secara signifikan.

Memang, dalam beberapa tahun terakhir penggiat usaha kopi semakin meningkat. Konsepnya pun beragam, mulai dari warung ataupun kedai kopi, café, coffee shop, dan berjualan dengan gerobak seperti Kopi Uda, bahkan dalam masa pandemi seperti ini. Oleh karena itu, dapat dikatakan persaingan kopi di Kabupaten Sintang semakin hari semakin ketat.

Menghadapi hal ini sangat penting untuk melakukan aktivitas komunikasi pemasaran terhadap produk-produk jualan melihat kondisi para pedagang-pedagang di sekitar Alun-Alun, khususnya bagi Kopi Uda. Artinya, komunikasi pemasaran mempunyai peran penting bagi Kopi Uda untuk bagaimana mengenalkan produk minuman dengan berbagai varian serta memberikan penawaran menarik bagi pembeli.

Berdasarkan latar belakang di atas, penulis tertarik untuk melakukan penelitian yang berjudul: Strategi Komunikasi Pemasaran Selama Masa Pandemi Covid-19 (Studi Pada Kopi Uda di Alun-Alun Kapuas Kabupaten Sintang).

Selanjutnya dalam Ngalimun (2017), Effendi Gazali membagi fungsi komunikasi menjadi 4, yaitu:

1. To inform, yaitu memberikan informasi kepada orang lain tentang suatu peristiwa, masalah, pendapat, pikiran, segala tingkah laku orang lain dan apa yang disampaikan kepada orang lain.

2. To educate, yaitu berfungsi menyampaikan pengetahuan agar dapat dimengerti serta memberikan pendidikan bagi yang membutuhkan.

3. To entertain, yaitu bertujuan untuk menyampaikan hiburan atau menghibur orang lain.

4. To influence, yaitu mempengaruhi setiap individu yang berkomunikasi dengan cara saling mempengaruhi jalan pikiran komunikan dan lebih jauh lagi berusaha mengubah sikap dan tingkah laku komunikan sesuai dngan yang diharapkan.

Di samping itu, menurut Kotler dan Keller (2012) komunikasi pemasaran terbagi menjadi delapan bidang aktivitas utama, yaitu:

1. Iklan adalah semua bentuk terbayar dari presentasi non personal dan promosi ide, barang atau jasa melalui sponsor yang jelas melalui media cetak (koran dan majalah), media penyiaran (radio dan televisi), media jaringan (telepon, kabel satelit, wireless), media elektronik (rekaman suara, rekaman video, CDROM, halaman website), dan media pameran (billboard, papan petunjuk jalan, dan poster). 
2. Promosi adalah berbagai insentif jangka pendek untuk mendorong percobaan atau pembelian produk atau jasa termasuk promosi konsumen (seperti sampel, kupon, dan permi), promosi perdagangan (seperti iklan dan tunjangan), dan promosi tenaga penjualan (kontes untuk reputasi).

3. Acara dan Pengalaman adalah kegiatan dan program yang disponsori perusahaan yang dirancang untuk menciptakan interaksi harian atau merek khusus, terkait interaksi dengan konsumen, termasuk seni olahraga, hiburan, dan acara serta kegiatan kurang formal.

4. Hubungan Masyarakat adalah beragam program yang diarahkan secara internal kepada karyawan dari perusahaan atau konsumen luar, perusahaan lain, pemerintahan, dan media untuk mempromosikan atau melindungi citra perusahaan atau produk komunikasi individu.

5. Pemasaran Langsung adalah penggunaan surat, telepon, faximile, email, atau internet untuk berkomunikasi secara langsung dengan atau meminta respon atau dialog dari pelanggan dan prospek tertentu.

6. Pemasaran Interaktif adalah kegiatan dan program online yang dirancang untuk melibatkan pelanggan atau prospek dan secara langsung atau tidak langsung meningkatkan kesadaran, memperbaiki citra atau menciptkan penjualan produk dan jasa.

7. Pemasaran dari Mulut ke Mulut adalah komunikasi lisan, tertulis, dan elektronik antar masyarakat yang berhubungan dengan keunggulan atau pengalaman pembeli atau menggunakn produk atau jasa.

8. Penjualan Personal adalah interaksi tatap muka dengan satu atau lebih pembeli prospektif untuk tujuan melakukan presentasi, menjawab, dan pengadaan pesanan.

\section{Metode Penelitian}

Penelitian ini menggunakan pendekatan kualitatif. Menurut Sugiyono (2011) pendekatan kualitatif adalah metode yang berdasarkan pada filsafat post-positivisme, sedangkan untuk meneliti pada objek ilmiah, di mana peneliti adalah sebagai instrument kunci, teknik pengumpulan data dilakukan dengan cara triangulasi (gabungan). Jenis penelitian yang akan digunakan penulis pada penelitian ini adalah kualitatif deskriptif yang bertujuan untuk memperoleh pemahaman yang mendalam mengenai makna, kenyataan, dan fakta yang relevan. Dalam penelitian ini pendekatan kualitatif akan membantu penulis untuk menjelaskan secara deskriptif bagaimana strategi komunikasi pemasaran yang dilakukan Kopi Uda selama masa pandemi COVID-19.

Strategi penelitian yang digunakan oleh penulis adalah studi kasus. Robert $\mathrm{K}$ Yin (2008) mendefinisikan studi kasus sebagai proses pencarian pengetahuan yang empiris guna menyelidiki dan meneliti berbagai fenomena dalam konteks kehidupan nyata.

Subjek dalam penelitian ini adalah Kopi Uda yang beralamat di Alun-Alun Sungai Kapuas Jalan Pembangunan, Tanjung Puri, Kabupaten Sintang. Sedangkan objek dalam penelitian ini adalah strategi komunikasi pemasaran yang dilakukan oleh Kopi Uda selama masa pandemi COVID-19. 
Data pada penelitian ini dikumpulkan penulis dengan melakukan:

1. Observasi

Sugiyono (2011) mendefinisikan observasi sebagai suatu proses yang kompleks dan tersusun dari pelbagai proses biologis dan psikologis yang mengacu pada proses pengamatan dan ingatan.

2. Wawancara

P. Joko Subagyo (2011) mendefinisikan wawancara sebagai suatu kegiatan yang dilakukan untuk mendapatkan informasi secara langsung dengan mengungkapkan pertanyaan-pertanyaan pada para responden. Wawancara bermakna berhadapan langsung antara interview dengan responden dan kegiatannya dilakukan secara lisan.

3. Studi Pustaka

Sugiyono (2012) menyebutkan bahwa studi kepustakaan berkaitan dengan kajian teoritis dan referensi lain yang berkaitan dengan nilai, budaya dan norma yang berkembang pada situasi sosial yang diteliti, selain itu studi kepustakaan sangat penting dalam melakukan penelitian karena penelitian tidak akan lepas dari literatur-literatur.

4. Dokumentasi

Moleong (2012) menyebutkan bahwa dokumen pribadi adalah catatan kejadian nyata seseorang secara tertulis tentang tindakan, pengalaman, dan kepercayaannya.

\section{Hasil Temuan dan Diskusi}

Kopi Uda merupakan kedai kopi kekinian yang menyajikan minuman dengan berbagai varian rasa serta dengan menu makanan tambahan yaitu seblak. Kopi Uda didirikan sejak Februari 2020 di Alun-Alun Kota Sintang. Milki dan Ika yang merupakan pendiri Kopi Uda notabenenya adalah penikmat kopi. Milki sendiri mempunyai latar belakang bekerja sebagai barista di salah satu kedai kopi. Pada saat itulah ia belajar banyak bukan hanya tentang kopi tetapi hal-hal yang menyangkut di dalamnya seperti pemasaran atau pelayanan.

Tidak hanya itu, keluarga besar Milki dan Ika juga berasal dari latar belakang yang sama di mana sudah membangun usaha kopi sejak dulu namun dengan konsep yang berbeda yaitu kedai kopi konvensional atau biasa disebut warung kopi. Hal ini membuat Milki dan Ika sangat familiar dengan kopi. Oleh karena itu, sejak Milki dan Ika kembali ke kota Sintang, mereka memutuskan untuk membangun bisnis kedai Kopi Uda. Milki dan Ika mendirikan Kopi Uda dengan tujuan untuk memperkenalkan warna selera baru yang tidak monoton kepada pecinta kopi maupun non-kopi dengan inovasi-inovasi mereka.

Pada Desember 2019, untuk pertama kalinya China melaporkan adanya penyakit baru yaitu pemberitahuan tentang adanya sejenis Pneumonia yang penyebabnya tidak diketahui. Sejak saat itu, peningkatan kasus Covid-19 terus terjadi dan menyebar di berbagai negara termasuk Indonesia.

Dalam perkembangannya, tepatnya pada 2 Maret 2020 pemerintah mengumumkan dua kasus positif Covid-19 pertama di Indonesia. Sejak adanya pandemi ini, hampir seluruh sektor terdampak, tak hanya kesehatan tetapi seperti sektor pendidikan, pembangunan, sosial, ekonomi dan lainnya.

Hal ini dirasakan oleh hampir semua lapisan masyarakat di Indonesia, salah satunya Kabupaten Sintang, Kalimantan Barat. Masyarakat Kabupaten Sintang juga 
merasakan dampak yang luar biasa di semua sektor. Banyak UMKM yang terpaksa berhenti sementara atau permanen karena banyak faktor yang mempengaruhi. Banyaknya PHK karena perkantoran atau perusahaan ingin memangkas pengeluaran, dan terjadi banyaknya pengangguran. Dalam hal ini Kopi Uda juga terkena dampak pandemi COVID-19 terhadap penjualannya.

Sesuai dengan fungsi komunikasi menurut Effendi Gazali dalam Ngalimun (2017), terdapat 4 fungsi utama komunikasi, pada fungsi komunikasi to inform Kopi Uda memberikan informasi mengenai varian produk-produknya. Informasi yang diberikan ini dilakukan oleh Kopi Uda disebarkan dengann menggunakan media komunikasi maupun tatap muka secara langsung melalui berbagai kesempatan.

Pada fungsi komunikasi to educate Kopi Uda mencoba memberikan edukasi atau pengetahuan mengenai bahan kopi yang baik dalam pembuatan kopi. Meskipun Kopi Uda hanya kedai kopi gerobak namun kopi yang digunakan merupakan biji kopi terbaik. Oleh karena itu pelanggan dapat menikmati minuman kopi dari biji kopi terbaik yang jarang menjadi perhatian para penjual kopi di tempat lain.

Pada fungsi komunikasi to entertain Kopi Uda biasanya melakukannya pada saat-saat tertentu yang istimewa seperti peringatan hari berdirinya Kopi Uda, perayaan hari kemerdekaan 17 Agustus, hari Sumpah Pemuda 28 Oktober atau sekedar di akhir pecan dengan mengadakan promo-promo potongan harga produk Kopi Uda atau halhal lainnya. Terakhir, pada fungsi komunikasi to influence Kopi Uda kembali mengajak masyarakat terutama anak-anak muda sebagai generasi milenial untuk mengonsumsi kopi dengan bahan pilihan terbaik.

R. Wayne Pace dan Brent D dalam (Effendy, 2011) menyebutkan terdapat tiga tujuan sentral dalam strategi komunikasi yaitu pertama adalah to secure understanding di mana Kopi Uda berusaha mengubah persepsi bahwa menikmati minuman kopi atau nonkopi tidak hanya di warung kopi atau tempat-tempat menjual kopi dengan harga tinggi, namun dapat juga menikmati minuman kopi atau nonkopi dengan kualitas terbaik dan rasa yang tidak kalah dengan harga yang terjangkau serta dengan suasana yang lebih santai. Kedua, to establish acceptance di mana Kopi Uda harus membina hubungan baik dengan para pelanggan agar dapat mempertahankan persepsi masyarakat mengenai produk-produk Kopi Uda agar tetap dapat bertahan di kala banyaknya pesaing-pesaing sejenis yang semakin bertambah dan terutama dalam mengahadapi kondisi ekonomi yang tidak stabil akibat Pandemi COVID-19. Ketiga, to motive action di mana Kopi Uda melakukan komunikasi langsung dengan para pelanggan dengan memberikan informasi menarik mengenai produk-produk Kopi Uda yang berbeda dengan varian minuman kedai lainnya mengingat masih banyak masyarakat di Sintang yang kurang tahu-menahu banyak mengenai varian minuman yang berasal dari luar.

Menurut Kotler dan Keller (2012) komunikasi pemasaran terbagi menjadi delapan bidang aktivitas utama, yaitu iklan, promosi, acara dan pengalaman, hubungan masyarakat, pemasaran langsung, pemasaran interaktif, pemasaran mulut ke mulut, dan penjualan personel. Kopi Uda dalam menstabilkan penjualannya menghadapi situasi pandemi COVID-19 mencoba untuk melaksanakan delapan bidang aktivitas utama komunikasi pemasaran tersebut dan beberapa di antaranya memberikan efek yang baik.

Dari kedelapan kegiatan strategi komunikasi yang dilakukan Kopi Uda, hanya beberapa saja yang dianggap efektif bagi Kopi Uda yaitu promosi, hubungan masyarakat dan pemasaran. Menurut Milky dan Ika dalam wawancara dengannya, alasan tiga kegiatan strategi komunikasi yang berjalan efektif adalah karena dibantu 
dengan penggunaan media sosial yang dapat menjangkau banyak orang sejak awal memulai usahanya.

Tidak dapat dipungkiri bahwa banyak orang yang berketergantungan terhadap penggunaan media sosial terutama kalangan remaja yang di mana merupakan sasaran utama dari produk-produk Kopi Uda. Milky dan Ika menambahkan apalagi ditambah dengan hadirnya jasa ojek online di Sintang yang sangat membantu penjualan ketika banyak orang memilih untuk tetap di rumah dalam kondisi pandemi ini.

\section{Simpulan}

Dalam penelitian yang dilakukan oleh penulis ada beberapa hal yang disimpulkan oleh penulis, yaitu:

1. Bidang aktivitas utama komunikasi pemasaran yang paling sering digunakan Kopi Uda adalah promosi, hubungan masyarakat dan pemasaran langsung di mana ketiga aktivitas tersebut dibantu dengan penggunaan media sosial yang dapat menjangkau banyak orang. Hal ini terlihat dari banyaknya konten promosi, aktivitas hubungan masyarakat, aktivitas pemasaran langsung yang dilakukan oleh Kopi Uda dalam memasarkan produk-produknya. Penggunaan media sosial secara rutin menunjukkan bahwa Kopi Uda sadar akan pentingnya pemasaran yang ditujukan kepada publik terutama para kaum remaja.

2. Dalam menstabilkan ataupun meningkatkan bisnis Kopi Uda terutama pada masa pandemi COVID-19, Kopi Uda menyadari pentingnya melakukan strategi komunikasi pemasaran yang berbeda, menarik dan secara intens mengingat banyaknya persaingan dan dampak pandemi di hampir semua sektor terhadap banyak orang.

3. Penulis menyimpulkan hambatan Kopi Uda dalam melakukan strategi komunikasi pemasaran adalah kondisi pasar akibat pandemi COVID-19 yang menjadi tidak menentu serta ditambah lagi dengan adanya peraturan pemerintah yang mana di satu sisi menjadi bumerang bagi aktivitas jual beli di lokasi.

\section{Ucapan Terima Kasih}

Peneliti ingin mengucapkan terima kasih kepada Fakultas Ilmu Komunikasi Universitas Tarumanagara, narasumber, serta semua pihak yang turut membantu peneliti sehingga penelitian ini dapat diselesaikan.

\section{Daftar Pustaka}

Effendy, Onong Uchjana. 2011. Ilmu Komunikasi Teori dan Praktek. Bandung: Remaja Rosdakarya.

Moleong. Lexy J. 2012. Metodologi Penelitian Kualitatif. Bandung: Remaja Rosdakarya.

Ngalimun. 2017. Ilmu Komunikasi Sebuah Pengantar Praktis. Yogyakarta: Pustaka Baru Press.

Kotler, Philip \& Kevin Lane Keller. 2012. Manajemen Pemasaran. Jakarta: Erlangga. Subagyo, P. Joko. 2011. Metodolgi Penelitian Dalam Teori dan Praktek. Jakarta: Aneka Cipta.

Sugiyono. 2011. Metode Penelitian Kuantitatif dan Kualitatif. Bandung: Alfabeta. 
Aldona Nevi Caroline, Farid Rusdi: Strategi Komunikasi Pemasaran selama Masa Pandemi COVID19 (Studi Kopi Uda di Alun-Alun Sungai Kapuas Kabupaten Sintang)

Sugiyono. 2012. Memahami Penelitian Kualitatif. Bandung: Alfabeta.

Yin, Robert K. 2008. Case Study Research: Design and Methods (Applied Social Research Method). Illinois: Sage Publications, Inc. 